\title{
PENGARUH TERAPI KOGNITIF PERILAKUAN UNTUK MENURUNKAN GANGGUAN PERILAKU MENENTANG PADA SISWA MTS X DI YOGYA- KARTA
}

\section{EFFECT OF COGNITIVE BEHAVIORAL THERAPY FOR REDUCING THE BEHAVIOR DISORDERS IN STUDENTS AGAINST MTS X IN YOGYAKARTA}

\author{
Magister psikologi profesi Universitas Mercu Buana Yogyakarta \\ Wahyu Kurniawan \\ E-mail: bangkaku25@yahoo.co.id
}

\begin{abstract}
Intisari
Penelitian ini bertujuan untuk mengetahui Pengaruh Terapi Kognitif perilakuan untuk menurunkan gangguan perilaku menentang. Hipotesis yang diajukan pada penelitian ini adalah ada perbedaan frekuensi gangguan perilaku menentang antara sebelum dan sesudah diberikan terapi kognitif perilakuan kepada siswa MTS X di Yogyakarta. Subjek yang diberikan terapi kognitif perilakuan mengalami penurunan frekuensi gangguan perilaku menentang di sekolah. Subjek dalam penelitian sebanyak 4 orang siswa MTS X kelas 8. Desain yang digunakan dalam penelitian ini adalah single case study berupa pengaruh terapi kognitif perilakuan. Metode analisis yang digunakan analisis, visual inspection, wawancara serta observasi dan analisis non parametrik (Wilcoxon). Hasil uji hipotesis pada terapi ini ialah $\mathrm{Z}$ sebesar $=0,034(\mathrm{p}>0,05)$, Berdasarkan analisis tersebut berarti bahwa ada perbedaan penurunan frekuensi gangguan perilaku menentang antara sebelum dan sesudah diberikan terapi kognitif perilakuan pada siswa MTS X kelas 8 di Yogyakarta.
\end{abstract}

Kata kunci : Terapi kognitif perilakuan, Gangguan perilaku menentang

\begin{abstract}
This study aimed to determine the effect of Cognitive Therapy Behavioral to reduce behavioral disorders opposed. Hypothesis proposed in this study is that there is a difference frequency between the opposing behavioral disorders before and after cognitive therapy to students behavioral MTS X in Yogyakarta. Subjects were given cognitive therapy behavioral decreased frequency of behavioral disorders in school against. Subjects in the study of 4 students of class X MTS 8. The design used in this study was a single case study in the form of cognitive therapy behavioral influence. The method of analysis used analysis, visual inspection, interview and observation and analysis of non-parametric (Wilcoxon). The results of hypothesis testing in this therapy is $Z$ for $=0.034$ ( $p>0.05$ ), Based on the analysis means that there are differences in the frequency of behavioral disorders oppose decrease between before and after cognitive therapy behavioral on MTS X grade 8 students in Yogyakarta.
\end{abstract}

Keywords: Cognitive therapy behavioral, oppositional defiant disorders 
Perilaku disruptif ialah perilaku yang dianggap bermasalah dalam konteks norma sosial yang ada di masyarakat. Biasanya individu dengan perilaku disruptif kerap kali tidak dapat menjalin hubungan yang baik, lepas kendali, tidak disukai oleh beberapa kalangan di masyarakat (Achenbach \& Edelbrock dalam Matthys\& Lochman 2010). Fenomena perilaku disruptif pada masa anak-anak dan remaja berdasarkan penelitian yang dilakukan oleh Connor (Klykyo \& Kay, 2010) menunjukkan bahwa terdapat $20 \%$ anakanak hingga remaja diindikasikan mengalami gangguan perilaku disruptif. Sedangkan menurut APA di tahun 1994 (Ammerman, 2006) terdapat 2 hingga $16 \%$ anak-anak hingga remaja yang mengalami perilaku disruptif di dunia.

Perilaku disruptif berdasarkan DSM-IV (APA,2000), dapat digolongkan dalam tiga bentuk: ADHD, perilaku menentang dan perilaku merusak. Salah satu bentuk perilaku disruptif yang paling sering muncul pada masa anak-anak hingga remaja adalah gangguan perilaku menentang (Doll dalam Nevid, 2005). Gangguan perilaku menentangadalah suatu pola negativistik, permusuhan, dan perilaku menentang yang menerus tanpa adanya pelanggaran yang serius terhadap norma sosial atau hak orang lain. Individu yang mengalami gangguan perilaku menentangsering berdebat dengan orangtua, kehilangan kendali, marah, benci, dan mudah mengganggu oleh orang lain, mereka cenderung menyalahkan orang lain atas kesalahan dan kekeliruan mereka sendiri. Manisfestasi dari gangguan ini hampir ditemukan di rumah kemudian ditunjukan di luar rumah (DSM dalam Kaplan \&Sadock, 1997).

Gangguan perilaku menentang lebih sering dialami anak laki-laki dibandingkan perempuan, dengan perbandingan 3:1. Biasanya individu dengan gangguan ini tidak memandang dirinya menentang tetapi mereka mengakui jika mereka menentang. Gangguan perilaku menentang didiagnosis ketika seorang anak menampilkan pola persisten atau konsisten pembangkangan, ketidakpatuhan permusuhan, dan terhadap berbagai figur otoritas termasuk orang tua, guru, dan orang dewasa lainnya. Gangguan perilaku menentang ditandai dengan masalah perilaku seperti terus-menerus berjuang dan berdebat, yang sensitif atau mudah terganggu, dan sengaja mengganggu atau menjadi dengki dan dendam kepada orang lain. Individu dengan gangguan perilaku menentang mungkin berulang kali kehilangan kendali mereka, berdebat dengan orang dewasa, sengaja menolak untuk mematuhi permintaan atau aturan orang dewasa, menyalahkan orang lain untuk kesalahan mereka sendiri, dan menjadi berulang kali marah dan kesal, keras kepala dan pengujian batas yang umum. Perilaku ini menyebabkan kesulitan yang signifikan dengan keluarga dan teman-teman dan di sekolah atau bekerja (Semiun, 2006).

Berdasarkan informasi yang dihimpun oleh komisi nasional perlindungan anak (2009) terdapat peningkatan angka perilaku menyimpang yang terjadi di kalangan remaja. Hal ini dibuktikan dengan adanya data sejak Januari 2009 meningkat menjadi $35 \%$ dibandingkan data sebelumnya. Pelaku rata-rata berusia 13-17 tahun. Perilaku yang menyimpang tersebut merupakan gangguan menyimpang yang diawali dengan munculnya gejala gangguan perilaku menentang (Loeber, dalam Carr, 2001). Berdasarkan hasil penelitian yang dilakukan oleh Greene (Ammerman, 2006) menunjukkan bahwa terdapat 2 hingga $16 \%$ anak-anak dan remaja diindikasikan mengalami perilaku gangguan perilaku menentang. Sedangkan penelitian yang dilakukan oleh Sanders, Gooley dan Nicholas (Hairina, 2010) menunjukkan bahwa prevalensi secara umum dari gangguan perilaku gangguan perilaku me- 
nentang berkisar antara 6 hingga $10 \%$. Sejalan dengan hal tersebut, Anggold dan Castello (Hairinia, 2010) menyatakan bahwa gangguan perilaku menentang adalah sebuah masalah kesehatan masyarakat yang sangat besar dengan prevalensi 5 hingga $10 \%$ dialami oleh anak-anak yang berusia antara 8 hingga 16 tahun. Masalah tersebut juga ditemukan dibeberapa negara Australia (Al-Yaman \& Sargeant dalam Fresher, 2008) yang melaporkan bahwa dari tahun 1999-2000 anak anak yang berusia 1 hingga 14 tahun, dilaporkan mengalami gangguan perilaku menentang. Namun di Indonesia sendiri belum ada data yang pasti mengenai berapa besaran prosentase atau jumlah anak dan remaja yang mengalami gangguan perilaku menentang (Tambunan dalam, Hairini 2010).

Remaja merupakan aset terbesar dalam pembangunan. Hal ini berarti kelompok remaja harus dipersiapkan sedemikian rupa agar remaja tersebut tumbuh dan berkembang menjadi generasi muda yang tangguh. Ketangguhan dalam hal ini terutama dilihat dari segi mental, berjiwa ksatria, kreatif, inovatif dan produktif (Purwanti dalam Kurniawan, 2011). Dalam perkembangannya, remaja dibagi menjadi tiga tahapan yaitu remaja awal 12-15 tahun, remaja madya $15-18$ tahun, dan remaja akhir 18-21 tahun (Monks, dkk, 2001). Kohleberg (Desmita, 2013) menjelaskan pada usia anak 10 hingga 16 tahun memang merupakan masa yang cukup dilematis dimana remaja harus memilih antara tindakan yang beraturan dalam memenuhi kebutuhan hidup atau dengan cara bertentangan dengan peraturan. Walaupun demikian, remaja sudah mampu mengenal konsep konsep moralitas yang baik, bersikap jujur, sopan, mampu menjadi pribadi yang disiplin.

Berdasarkan hasil wawancara yang peneliti lakukan kepada kepala sekolah di MTS X di Yogyakarta pada bulan Januari 2014, Kepala sekolah menyatakan bahwa terdapat 5 siswa laki-laki yang sering dilaporkan sebagai siswa yang kerap kali menentang, hal ini diketahui berdasarkan laporan beberapa guru yang mengajar di kelas. Ketika 5 siswa tersebut saat berada di dalam kelas, kelima siswa tersebut kerap melakukan agenda di luar kegiatan belajarnya seperti keluar masuk kelas, mengabaikan tugas yang diberikan oleh gurunya, memainkan handphone, bercerita, tidak mengerjakan tugas ketika guru mengajar. Tidak hanya persoalan di atas saja, kelima siswa tersebut kerap kali mengganggu temannya yang lain seperti mengambil buku temannya, mendorong meja dan kursi temannya, memindahkan tas temannya ketika belajar, walaupun kelima siswa tersebut mengganggu temannya yang lain, kelima siswa tersebut kerap kali marah bila teman-temannya yang lain melaporkan kesalahan yang dilakukan kepada guru di kelas. Informasi yang lain ditambahkan pula, kelima siswa tersebut kerap kali menentang aturan yang ada di sekolah, seperti tidak mengenakan pakaian yang formal dan sepatu formal. Hal lain pula dilaporkan kelima siswa tersebut kerap kali melawan bila beberapa guru memberikan teguran kepada kelima siswa tersebut agar bisa mengikuti peraturan sebagaimana anak-anak yang lain, kelima siswa tersebut pula dilaporkan kerap bolos sekolah. Bila diukur dalam satuan minggu kelima siswa tersebut hanya masuk selama 4 hari. Kelima siswa tersebut pula bila diukur dalam buku agenda guru BK di sekolah selalu dipanggil dan selanjutnya diberikan skor ke dalam buku hitam.

Hasil wawancara tersebut kemudian diperkuat dengan observasi yang peneliti lakukan di lapangan yang menunjukan bahwa kelima siswa tersebut terlihat melakukan kegiatan di luar kegiatan belajar di sekolah, hal ini dilihat ketika pada saat siswa yang lain melakukan kegiatan belajar, kelima siswa tersebut terlihat disibuk- 
kan dengan agenda yang tidak ada hubungannya dengan belajar seperti keluar masuk kelas, bermain handphone, berbicara dengan temannya yang lain, dan sesekali pula, kelima siswa tersebut menganggu temannya yang lain, seperti mendorong temannya ketika belajar, merebut buku, pena dan alat alat tulis. Ketika guru-guru memberikan arahan, kelima siswa tersebut tidak memperdulikan arahan yang diberikan oleh gurunya, dan tidak hanya hal ini saja, kelima siswa tersebut terlihat kerap kali mengeluarkan pernyataan yang bersikap menentang seperti “ Saya tidak mau, saya malas, capek, ngapain dibuat tugasnya toh kami hanya mau maen maen aja di sekolah". Sehingga terkadang beberapa permasalahan tersebut menjadikan guru di kelas menjadi kurang simpatik untuk mengajar dan membuat kelima anak tersebut sering dimintakan untuk meninggalkan kelas dalam kondisi belajar.

Berbagai fenomena yang dimunculkan di atas tentu berdampak pada perolehan prestasi belajar siswa di sekolah. Hal ini diperkuat dengan pernyataan yang dikemukakan oleh Kepala sekolah MTS X Yogyakarta, yang menyatakan bahwa hal tersebut berdampak pada prestasi belajar yang dimiliki kelima siswa tersebut. Kelima siswa tersebut selalu mendapatkan nilai yang buruk, selalu berada pada peringkat kelas yang terbawah, dan hampir tidak dinaikkan. Hal ini dikarenakan kelima siswa tersebut jarang mengumpulkan tugas, tidak pernah tuntas dalam mengerjakan tugas belajar, selalu tidak memperhatikan apa yang disampaikan oleh gurunya, menolak untuk belajar, keluar masuk kelas, serta tidak mau mendengarkan saran yang diberikan oleh guru-guru di kelas. Pihak sekolah pula pernah melaporkan hal tersebut kepada pihak keluarga namun kelima siswa tersebut tetap melakukan hal yang sama.

Faktor penyebab dari gangguan perilaku menentang, sampai saat sekarang masih belum diketahui secara pasti, namun sebagian ahli meyakini bahwa perilaku ini merupakan ekspresi dari temperamen anak yang digambarkan sebagai tipe anak yang sulit diatur atau dikenal dengan difficult child (Rey dalam Nevid, 2005). Sedangkan menurut Mash \& Wolfe (2005) faktor yang mempengaruhi perilaku gangguan perilaku menentang ialah disebabkan beberapa faktor antara lain ialah faktor individu, faktor keluarga dan faktor lingkungan yang buruk. Adapun penjelasan dari faktor individu ialah antara lain disebabkan tempramental yang difficult cenderung tampil sebagai anak yang aktif, sulit ditenangkan, sangat sensitif terhadap stimulus yang berasal dari lingkungan dan sering menunjukan mood yang negatif. Selain berkaitan dengan tempramen, munculnya gangguan perilaku menentang ialah disebabkan oleh adanya distorsi kognitif yang dialami oleh remaja tersebut (Foulkrod \& Davenpord, 2010), dimana remaja tersebut cenderung menilai situasi sosial yang ambigu atau netral sebagai suatu situasi yang mengancam sehingga anak menampilkan gangguan perilaku menentang sebagai respon dari situasi yang mereka hadapi.

Dampak yang ditimbulkan dari adanya gangguan perilaku menentang terlihat pada saat remaja berada di lingkungan sekolah, antara lain: menjadi kurang mampu menunjukkan perilaku yang dapat mendukung keberhasilan akademis dan interaksi sosialnya seperti mematuhi atau menaati peraturan sekolah, kurang dapat mengerjakan tugas dengan baik, kurang memperhatikan guru dengan tenang atau belajar bersama dengan teman sehingga tidak jarang mereka memiliki prestasi yang rendah dan cenderung mengalami droup-out dari sekolah (Boyum \& Parker, 1995). Dari sisi akademis, akibat dari gangguan perilaku menentang ini, remaja biasanya akan mengalami kesulitan diajar di dalam kelas sehingga mengakibatkan prestasi akademiknya menjadi 
rendah dan mereka seringkali didiagnosis mengalami kesulitan belajar (Yanti, 2005). Remaja yang mengalami gangguan perilaku menentang seringkali gagal dalam ketrampilan sosial seperti berbagi, berempati, dan bernegosiasi, dimana ketrampilan ini penting untuk membangun persahabatan (Storey \& Slaby, 2008). Hal senada, didukung pernyataan yang disampaikan oleh Coie \& Dodge (Stratton \& Reid, 2004 dalam situs www.son.washington.edu.com) yang menyatakan bahwa remaja dengan gangguan perilaku menentang cenderung bermasalah dari sisi akademiknya, hal ini dikarenakan remaja tersebut jarang melakukan kegiatan belajar di kelas, mengabaikan pekerjaaan yang berhubungan dengan pelajaran, tidak hanya persoalan itu saja, remaja yang berperilaku gangguan perilaku menentang cenderung dijauhi, tidak disukai oleh beberapa guru dan teman di kelasnya.

Berbagai persoalan yang terjadi di atas, diperlukan sebuah penanganan yang komperehensif terhadap remaja yang memiliki kecenderungan gangguan perilaku menentang sehingga gangguan tersebut tidak menjadi semakin parah dan mengarahkan kepada gangguan berikutnya yaitu perilaku merusak (Lewis dalam Silver \& Ellison, 1995). Hal ini pula senada dengan pernyataan yang dikemukakan oleh Loeber (Yanti, 2005) yang menyatakan bahwa gangguan perilaku menentang apabila tidak ditangani maka perilaku tersebut akan meningkat menjadi perilaku merusak.

Terdapat beberapa intervensi yang dapat dilakukan untuk menangani gangguan perilaku menentang antara lain adalah melalui Parent-Child Interaction Therapy, Cogitive Behavioral Therapy, Prescriptive Play Therapy, Behavioral Parenting Therapy, Parent Management therapy (Matthys \& Lochman 2010). Pada penelitian ini, peneliti akan menggunakan
Cognitive Behavioral Therapy yang selanjutnya peneliti adaptasikan ke dalam bahasa Indonesia yang disebut pula dengan terapi kognitif perilakuan yang akan digunakan secara langsung kepada remaja yang mengalami kecenderungan gangguan perilaku menentang. Hal ini didukung oleh pernyataan yang dikemukakan oleh Adelman \& Taylor (2008) yang menyatakan bahwa terapi kognitif perilakuan sangat dimungkinkan diberikan kepada anak hingga remaja dengan gangguan perilaku seperti perilaku menentang dan perilaku merusak. Terapi kognitif perilakuan yang diberikan berhubungan dengan kemampuan sosial, problem solving dan angger management (Bierman, 1989; Kazdin et all, 1997; Louchman \& Dunn, 1993 ; Shure, 1994 dalam Webster-stratton \& Reid, 2003). Adapun alasan diberikan terapi kognitif perilakuan dikarenakan usia tersebut berada pada fase perkembangan dan pemikiran operasional formal (Lerner \& Hustlsch dalam Desmita, 2012). Pada tahapan operasional formal seharusnya remaja sudah mampu melakukan pengendalian kontrol diri sendiri, serta mampu membedakan baik dan buruk suatu perilaku (Piaget dalam Santrock, 2007). Hal serupa pula dikarenakan pada anak usia remaja mampu serta ikut terlibat dalam pengobservasian diri, mampu mengevaluasi performa yang sedang dilakukan menurut standar dan tujuan hidup serta mulai merefleksikan apa yang sedang dilakukannya (Bandura dalam Crain, 2007).

Hal lain pula dikarenakan didukung oleh penelitian sebelumnya antara lain ialah penelitian yang dilakukan oleh Ariati (2012) dengan teknik terapi kognitif perilakuan upaya menurunkan perilaku agresif pada remaja yang mengalami perilaku merusak, penelitian tersebut terbukti mampu mengurangi perilaku agresif pada remaja yang diindikasikan mengalami perilaku merusak. Penelitian yang lain pula pernah dilakukan oleh 
McCart, Priester, Davies \& Azen (2006), dalam penelitiannya menunjukan dengan pendekatan Behavioral Parent Training dan terapi kognitif perilakuan mampu mengurangi perilaku antisosial pada anak. Adapun penelitian tentang gangguan perilaku menentang yang menggunakan terapi kognitif perilakuan pernah dilakukan oleh Munardyansih (2007) pada anak usia sekolah, hasil yang ditunjukan ialah, ada perubahan perilaku terutama dalam pengendalian marah dan penurunan frekuensi marah pada anak yang mengalami gangguan perilaku menentang. Terapi kognitif perilakuan pula pernah diteliti oleh Nindita (2012) dalam pengupayaan pengelolaan marah pada anak yang dindikasikan mengalami kecenderungan perilaku gangguan perilaku menentang, penelitian tersebut terbukti menunjukan bahwa ada penurunan tingkat kemarahan pada anak-anak yang diindikasikan mengalami perilaku gangguan perilaku menentang.

Menurut Baker \& Scarth (2002) tujuan dari terapi kognitif perilakuan adalah untuk mengurangi perilaku yang bermasalah, dan meningkatkan perilaku. Sedangkan menurut Smith, Lochman \& Dauncin (2005), terapi kognitif perilakuan merupakan metode yang mengajarkan strategi kognitif dan mengkombinasikan dengan strategi perilaku yang efektif untuk membantu menurunkan hiperaktif atau impulsif dan perilaku disruptif lainnya. Pada remaja, terapi kognitif perilaku biasanya difokuskan pada kognitif sosial dan interpersonal problem-solving. Pendekatan ini bertujuan untuk memberikan kesempatan pada anak untuk mencoba sesuatu dan mengembangkan ketrampilan baru. Hal ini sejalan dengan target yang sebaliknya dibuat untuk proses intervensi yang akan dilakukan. Menurut Kazdin, terapi kognitif perilakuan memiliki target untuk meningkatkan ketrampilan komunikasi, problem solving, mengontrol impuls atau dorongan, dan angger management (Baker \& Scarth, 2002). Penanganan untuk mengubah distorsi kognitif adalah dengan mengajarkan strategi-strategi kognitif dan dikombinasikan dengan strategi perilaku, sehingga mempengaruhi kontrol diri dan kemampuan pemecahan masalahnya sehingga gangguan perilaku menentang akan dapat menurun (Smith, Lochman \& Daunic, 2005). Menurut Griffin, Huges, Kaplan, Kazdin (Matthys \& Lochman, 2010) upaya menangani gangguan perilaku menentang yang menggunakan terapi kognitif perilakuan harus disesuaikan dengan tahapan usia serta penilaian terlebih dahulu hal ini dikarenakan tingkat pemahaman yang ada di dalam individu sendiri tentu berbeda. Terapi kognitif perilakuan untuk kalangan remaja biasa dilakukan dengan melalui, Problem solving skill, Behavioral management, Modeling, Social problem solving, Cognitive restructuring, Relaxation and Self instructional training.

Griffin, Huges, Kaplan, Kazdin (dalam Matthys \& Lochman, 2010) menyatakan bahwa, program ini dapat mengurangi perilaku agresif, perilaku disruptif dan dapat meningkatkan kemampuan pemecahan masalah, keahlian sosial, refleksi kognitif serta kontrol diri yang baik bagi remaja yang mengalami gangguan perilaku menentang. Adapun tahapan program penanganan ini dapat dilakukan secara kelompok maupun individu yang berlangsung dalam 12 sesi, dalam setiap sesi menggunakan waktu 45 hingga 130 menit.

Berdasarkan penjelasan di atas, peneliti tertarik untuk melakukan penelitian yang dapat membantu remaja yang mengalami gangguan perilaku menentang. Penanganan yang akan dilakukan ialah dengan memberikan terapi kognitif perilakuan dalam upaya menurunkan gangguan perilaku menentang pada remaja. Terapi kognitif perilakuan yang diberikan pada remaja 
dalam penelitian ini mengacu pada teori yang dikemukakan oleh Griffin, Huges, Kaplan, Kazdin (Matthys \& Lochman, 2010) yaitu berupa Problem solving skill, Behavioral management, modeling, Social problem solving, Cognitive restructuring, Relaxation and self instructional training. Remaja akan diajak untuk memahami emosi yang selama ini mereka rasakan saat ada kejadian atau konflik yang membuat mereka alami sehingga memunculkan pola pikir yang mengharuskan mereka menentang. Kemudian remaja mampu mengontrol emosi sehingga tidak terjadi perilaku menentang. Hal ini juga akan dibantu dengan mengajarkan kepada remaja untuk mencari kemungkinan-kemungkinan pemecahan masalah yang lebih positif, lalu memutuskan pilihan tersebut. Hal ini dimasukkan agar remaja tidak lagi memilih perilaku menentang sebagai upaya menyelesaikan masalah di lingkungan sosial.

\section{METODE PENELITIAN}

\section{Peserta Penelitian}

Subjek dalam penelitian ini ialah siswa remaja awal dengan tingkat usia 12-15 tahun di MTS X Yogyakarta dengan jenis kelamin laki-laki sebanyak 5 orang yang memenuhi karakteristik gangguan perilaku menentang mengacu pada behavioral checklist yang peneliti adaptasikan dari DSM-IV (APA, 2000). Adapun hal lain yang perlu dipertimbangkan ialah mengenai IQ subjek. Wilding \& Milne (2013) menyatakan bahwa, subjek yang dapat diberikan terapi kognitif perilakuan harus diketahui terlebih dahulu kapasitas IQ subjek. Subjek dengan kapasitas IQ rata-rata hingga di atas rata-rata yang dapat diberikan terapi kognitif perilakuan. Berdasarkan keterangan yang dihimpun di atas, maka hanya terdapat 4 siswa yang akan dijadikan subjek dalam penelitian ini.

\section{Desain Penelitian}

Pada penelitian ini menggunakan rancangan Small-N design yang menggunakan desain A-B-A untuk mengetahui dari satu atau sedikit subjek secara lebih intensif (Myers \& Hansen, 2006). Tujuan dari penelitian ini adalah untuk mengetahui pengaruh Terapi Kognitif Perilakuan sebagai intervensi terhadap penurunan perilaku perilaku menentang pada remaja MTS X di Yogyakarta. Menurut Kazdin (2005) single case experimental design adalah desain penelitian untuk mengevaluasi efek dari suatu tritment dengan beberapa subjek dalam satu kelompok atau subjek yang diteliti adalah tunggal $(\mathrm{N}=2)$. Dalam penelitian ini dilakukan pengukuran berulang pada variabel tergantung, baik sebelum pemberian intervensi maupun setelah pemberian intervensi. Pelaksanaan penelitian ini melibatkan fase pengukuran baseline (A), Fase pemberian intervensi (B), dan fase pengukuran setelah perlakuan ditarik (A). rancangan desain penelitian ini dapat digambarkan sebagai berikut:

\begin{tabular}{|c|c|}
\hline $\begin{array}{c}01020304 \\
\mathrm{~A}\end{array}$ & $\begin{array}{c}\text { OX } \\
\mathrm{B}\end{array}$ \\
$\mathrm{A}$
\end{tabular}

Keterangan:

O1 : Pengukuran baseline 1

O2 : Pengukuran baseline 2

O3 : Pengukuran baseline 3

O4 : Pengukuran baseline 4

OX : Fase Intervensi

O5 : Pengukuran 1 setelah perlakuan dihentikan

O6 : Pengukuran 2 setelah perlakuan dihentikan

O7 : Pengukuran 3 setelah perlakuan dihentikan

O8 : Pengukuran 4 setelah perlakuan dihentikan

Pengukuran baseline awal dan pengukuran setelah perlakuan dihentikan dilakukan masing-masing selama 4 kali dan dilaksanakan se- 
lama 4 hari berturut-turut. Untuk menyimpulkan kecenderungan data hasil observasi, setidaknya diperlukan tiga kali observasi untuk fase baseline pada grafik yang disajikan (Barlow \& Hansen, 1984; Sunanto, Takeuchi \& Nakata, 2005).

\section{Metode Pengumpulan Data}

Metode pengumpulan data dilakukan dengan menggunakan wawancara dan pengamatan kepada subjek penelitian pada saat baseline, masa perlakuan, dan setelah diberikan perlakuan ditarik. Aspek aspek yang terkait dengan observasi yang dilakukan adalah berkaitan dengan gangguan perilaku menentang. Adapun panduan observasi ini dilakukan mengacu pada behavior cheklist yang dibuat oleh peneliti mengacu pada DSM IV (APA, 2000). Aitem dalam observasi ini mengukur besaran frekuensi kemunculan respon atau target perilaku subjek maka peneliti menggunakan tanda tally (/) untuk jumlah perilaku yang muncul. Adapun metode yang lain ialah menggunakan wawancara dan observasi

\section{Intervensi Penelitian}

Subjek dalam penelitian ini diberi perlakuan berupa terapi kognitif perilakuan yang terdiri dari beberapa materi antara lain: Behavioral management, modelling, social problem solving, cognitive restructuring dan self management. Pemberian perlakuan terapi kognitif perilakuan dilakukan dalam 12 sesi dengan waktu 45 menit hingga 130 menit dalam setiap sesi. Dalam setiap pertemuan subjek akan diberikan 5 sesi dalam setiap 1 kali pertemuan selama 2 hari. Adapun modul terapi kognitif perilakuan yang akan peneliti gunakan ialah mengacu pada teori yang dikemukakan oleh Griffin, Huges, Kaplan, Kazdin (Matthys \& Lochman, 2010) Pengukuran perilaku menentang pada baseline awal dan baseline akhir dilakukan selama 4 hari yang dimulai pada pukul 08.00-12.00.

Metode Analisis Data

Peneliti akan menggunakan metode analisis data dengan analisis visual atau visual inspection yaitu analisis data yang menginterpretasikan hasil melalui data grafik secara akurat dan bermakna dengan melihat perubahan yang terjadi dan melihat hubungan perubahan perilaku dengan pemberian intervensi (Coopper, Heron \& Heward dalam Ayu, 2012). Analisis statistik selanjutnya adalah dengan menggunakan teknik analisis Wilcoxon untuk menguji perbedaan perilaku menentang pada subjek sebelum diberikan terapi dan sesudah diberikan terapi (Seniati, 2013).

\section{HASIL PENELITIAN \\ HASIL}

\section{ANALISIS VISUAL INSPECTION}

Berikut data observasi berdasarkan hasil penilaian awal (Fase A 1) ketiga rater/observer dari sebelum pemberian terapi kognitif perilakuan hingga setelah pemberian terapi, adapun penjelasan dapat dijelaskan sebagai berikut:

\section{a. Subjek ADT}

Pengukuran dilakukan kepada subjek ADT melalui tiga rater, yang dilakukan melalui tiga tahapan pengukuran antara lain ialah pengukuran awal, pemberian intervensi dan pengukuran akhir. Adapun hasil pengukuran tersebut dijelaskan pada Tabel di bawah ini:

Tabel 1 Data mentah skor pengukuran awal (Fase A1)

Subjek ADT

\begin{tabular}{|c|c|c|c|c|}
\hline \multirow{2}{*}{ Hari } & \multirow{2}{*}{ Waktu } & \multicolumn{3}{|c|}{$\begin{array}{l}\text { Skor total pengukuran awal } \\
\text { (A1) }\end{array}$} \\
\hline & & $\begin{array}{c}\text { Rater } \\
1\end{array}$ & Rater 2 & Rater 3 \\
\hline 1 & $\begin{array}{c}08.00- \\
12.00\end{array}$ & 20 & 24 & 24 \\
\hline 2 & $\begin{array}{c}08.00- \\
12.00\end{array}$ & 19 & 15 & 15 \\
\hline
\end{tabular}




\begin{tabular}{rrrrr}
3 & $\begin{array}{r}08.00- \\
12.00\end{array}$ & 20 & 18 & 18 \\
& $08.00-$ & 20 & 20 & 20 \\
\hline
\end{tabular}

Pada sesi terapi data mentah yang peneliti temukan dijelaskan pada Tabel di bawah ini:

Tabel 2 Data mentah skor pengukuran pada saat

\begin{tabular}{|c|c|c|c|c|}
\hline & & $(\mathrm{Fa}$ & & \\
\hline \multirow{2}{*}{ Hari } & \multirow{2}{*}{ Waktu } & \multicolumn{3}{|c|}{$\begin{array}{l}\text { Skor total pengukuran } \\
\text { tengah }(\mathrm{B})\end{array}$} \\
\hline & & $\begin{array}{c}\text { Rater } \\
1\end{array}$ & $\begin{array}{c}\text { Rater } \\
2\end{array}$ & Rater 3 \\
\hline 1 & $\begin{array}{c}08.00- \\
12.00\end{array}$ & 10 & 10 & 10 \\
\hline 2 & $\begin{array}{c}08.00- \\
12.00\end{array}$ & 6 & 6 & 6 \\
\hline
\end{tabular}

Berdasarkan keterangan di atas, maka terlihat bahwa terdapat penurunan frekuensi gangguan perilaku menentang yang dialami oleh subjek. Sedangkan fase berikutnya ialah fase setelah intervensi yang diberikan kepada subjek. Adapun penjelasan data, dapat dilihat pada Tabel 3di bawah ini:

Tabel 3 Data mentah skor pengukuran pada saat terapi (Fase A2)

\begin{tabular}{|c|c|c|c|c|}
\hline \multirow[t]{2}{*}{ Hari } & \multirow[t]{2}{*}{ Waktu } & \multicolumn{3}{|c|}{$\begin{array}{l}\text { Skor total pengukuran } \\
\text { akhir (A2) }\end{array}$} \\
\hline & & Rater 1 & Rater 2 & Rater 3 \\
\hline 1 & $\begin{array}{c}08.00- \\
12.00\end{array}$ & 13 & 13 & 13 \\
\hline 2 & $\begin{array}{c}08.00- \\
12.00\end{array}$ & 12 & 12 & 12 \\
\hline 3 & $\begin{array}{c}08.00- \\
12.00\end{array}$ & 12 & 12 & 13 \\
\hline 4 & $\begin{array}{l}08.00- \\
12.00\end{array}$ & 12 & 12 & 12 \\
\hline
\end{tabular}

Berdasarkan data mentah dari ketiga hasil pengukuran sebelum intervensi (A1), selama pemberian Intervensi (B), dan setelah pemberian intervensi (A2). Maka dapat dicari hasil rera- ta skor total dari ketiga rater. Berikut ini analisis data yang dihasilkan dari hasil observasi yang ditampilkan dalam bentuk grafik. Setiap grafik mewakili rerata skor total dari ketiga rater berdasarkan tingkat perilaku menentang anak pada saat baseline awal (A1) selama 4 hari, pemberian intervensi (B) selama 2 hari, dan Baseline akhir (A2) selama 4 hari.

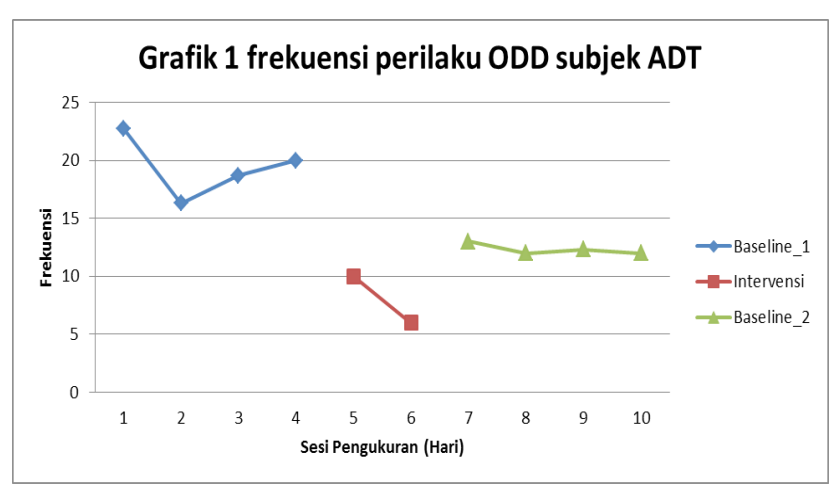

Berdasarkan data mentah dari ketiga hasil pengukuran sebelum intervensi (A1), selama pemberian Intervensi (B), dan setelah pemberian intervensi (A2). Maka dapat disimpulkan bahwa terdapat perubahan skor angka dari ketiga pengukuran di atas. Berdasarkan grafik pada gambar di atas tampak bahwa skor minimal frekuensi perilaku menentang pada pengukuran pada tahap awal (A1) ialah sebesar 16.3. Pada fase intervensi (B1) terlihat adanya perubahan grafik jika dibandingkan dengan sebelumnya ialah sebesar 6 , sedangkan pada fase pengukuran akhir nilai terendah ialah 12. Sehingga dapat disimpulkan bahwa terdapat penurunan perilaku pada subjek ADT baik sebelum dan sesudah diberikan intervensi.

\section{b. Subjek AD}

Pengukuran dilakukan kepada subjek AD melalui tiga rater, yang dilakukan melalui tiga tahapan pengukuran antara lain ialah pengukuran awal, pemberian intervensi dan pengukuran akhir. Adapun hasil pengukuran tersebut dijelaskan pada Tabel di bawah ini: 
Tabel 4 Data mentah skor pengukuran awal (Fase A1)

Subjek AD

\begin{tabular}{ccccc}
\multicolumn{5}{c}{ Subjek AD } \\
\hline \multirow{4}{*}{ Hari } & Waktu & \multicolumn{3}{c}{ Skor total pengukuran awal } \\
\cline { 3 - 5 } & & Rater 1 & Rater 2 & Rater 3 \\
& $08.00-$ & 15 & 15 & 14 \\
1 & 12.00 & & & \\
2 & $08.00-$ & 14 & 14 & 15 \\
& 12.00 & 14 & & \\
3 & $08.00-$ & 15 & 15 & 14 \\
& 12.00 & & & \\
4 & $08.00-$ & 15 & 15 & 14 \\
\hline
\end{tabular}

Pada sesi terapi data mentah yang peneliti temukan dijelaskan pada Tabel di bawah ini:

Tabel 5 Data mentah skor pengukuran pada saat

\begin{tabular}{|c|c|c|c|c|}
\hline \multirow[t]{2}{*}{ Hari } & \multirow[t]{2}{*}{ Waktu } & \multicolumn{3}{|c|}{$\begin{array}{c}\text { Skor total pengukuran } \\
\text { tengah }(\mathrm{B})\end{array}$} \\
\hline & & Rater 1 & Rater 2 & Rater 3 \\
\hline 1 & $\begin{array}{c}08.00- \\
12.00\end{array}$ & 4 & 4 & 4 \\
\hline 2 & $\begin{array}{c}08.00- \\
12.00\end{array}$ & 5 & 5 & 3 \\
\hline
\end{tabular}

Berdasarkan keterangan di atas, maka terlihat bahwa terdapat penurunan frekuensi gangguan perilaku menentang yang dialami oleh subjek. Sedangkan fase berikutnya ialah fase setelah intervensi yang diberikan kepada subjek. Adapun penjelasan data, dapat dilihat pada data di bawah ini:

Tabel 6 Data mentah skor pengukuran pada saat

\begin{tabular}{ccccc}
\multicolumn{5}{c}{ terapi (Fase A2) } \\
\hline \multirow{3}{*}{ Hari } & Waktu & \multicolumn{3}{c}{$\begin{array}{c}\text { Skor total pengukuran } \\
\text { akhir (A2) }\end{array}$} \\
\cline { 3 - 5 } 1 & & Rater 1 & Rater 2 & Rater 3 \\
& $08.00-$ & 10 & 10 & 9 \\
& 12.00 & 10 & & \\
2 & $08.00-$ & 8 & 8 & 8 \\
& 12.00 & & & \\
3 & $08.00-$ & 10 & 10 & 9
\end{tabular}

\begin{tabular}{lrrrrr}
4 & $08.00-$ & 8 & 8 & 8 \\
\hline
\end{tabular}

Berdasarkan data mentah dari ketiga hasil pengukuran sebelum intervensi (A1), selama pemberian Intervensi (B), dan setelah pemberian intervensi (A2). Maka dapat dicari hasil rerata skor total dari ketiga rater. Berikut ini analisis data yang dihasilkan dari hasil observasi yang ditampilkan dalam bentuk grafik. Setiap grafik mewakili rerata skor total dari ketiga rater berdasarkan tingkat perilaku menentang anak pada saat baseline awal (A1) selama 4 hari, pemberian intervensi (B) selama 2 hari, dan Baseline akhir (A2) selama 4 hari.

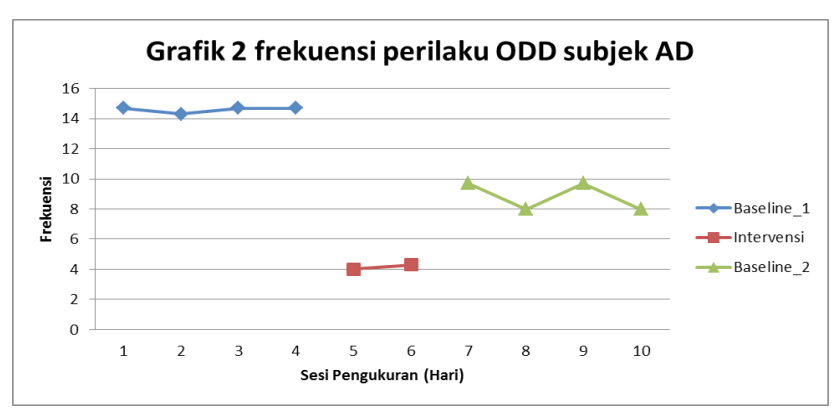

Berdasarkan data mentah dari ketiga hasil pengukuran sebelum intervensi (A1), selama pemberian Intervensi (B), dan setelah pemberian intervensi (A2). Maka dapat disimpulkan bahwa terdapat perubahan skor angka dari ketiga pengukuran di atas. Berdasarkan grafik pada gambar di atas tampak bahwa skor minimal frekuensi perilaku menentang pada pengukuran pada tahap awal (A1) ialah sebesar 14.3. Pada fase intervensi (B1) terlihat adanya perubahan grafik jika dibandingkan dengan sebelumnya ialah sebesar 4 sedangkan pada fase pengukuran akhir nilai terendah ialah 8. Sehingga dapat disimpulkan bahwa terdapat penurunan perilaku pada subjek AD baik sebelum dan sesudah diberikan intervensi.

\section{c. Subjek RD}

Pengukuran dilakukan kepada subjek RD melalui tiga rater, yang dilakukan melalui tiga 
tahapan pengukuran antara lain ialah pengukuran awal, pemberian intervensi dan pengukuran akhir. Adapun hasil pengukuran tersebut dijelaskan pada Tabel di bawah ini:

Tabel 7 Data mentah skor pengukuran awal (Fase A1)

Subjek RD

\begin{tabular}{|c|c|c|c|c|}
\hline \multirow[t]{2}{*}{ Hari } & \multirow[t]{2}{*}{ Waktu } & \multicolumn{3}{|c|}{$\begin{array}{c}\text { Skor total pengukuran } \\
\text { awal (A1) }\end{array}$} \\
\hline & & Rater 1 & Rater 2 & Rater 3 \\
\hline 1 & $\begin{array}{c}08.00- \\
12.00\end{array}$ & 19 & 17 & 17 \\
\hline 2 & $\begin{array}{c}08.00- \\
12.00\end{array}$ & 16 & 16 & 20 \\
\hline 3 & $\begin{array}{c}08.00- \\
12.00\end{array}$ & 15 & 15 & 15 \\
\hline 4 & $\begin{array}{c}08.00- \\
12.00\end{array}$ & 16 & 16 & 17 \\
\hline
\end{tabular}

Pada sesi terapi data mentah yang peneliti temukan dijelaskan pada Tabel di bawah ini:

Tabel 8 Data mentah skor pengukuran pada saat

\begin{tabular}{ccccc}
\multicolumn{5}{c}{ terapi (Fase B) } \\
\hline \multirow{3}{*}{ Hari } & Waktu & \multicolumn{3}{c}{$\begin{array}{c}\text { Skor total pengukuran } \\
\text { tengah (B) }\end{array}$} \\
\cline { 3 - 5 } & & Rater 1 & Rater 2 & Rater 3 \\
& & & & \\
1 & $08.00-$ & 7 & 6 & 6 \\
& 12.00 & & & \\
2 & $08.00-$ & 6 & 5 & 5
\end{tabular}

Berdasarkan keterangan di atas, maka terlihat bahwa terdapat penurunan frekuensi gangguan perilaku menentang yang dialami oleh subjek. Sedangkan fase berikutnya ialah fase setelah intervensi yang diberikan kepada subjek. Adapun penjelasan data, dapat dilihat pada data di bawah ini:
Tabel 9 Data mentah skor pengukuran pada saat terapi (Fase A2)

Skor total pengukuran akhir

\begin{tabular}{ccccc} 
Hari & Waktu & \multicolumn{3}{c}{$(\mathrm{A} 2)$} \\
\cline { 3 - 5 } & & Rater 1 & Rater 2 & Rater 3 \\
& $08.00-$ & 10 & 10 & 9 \\
& 12.00 & & & \\
2 & $08.00-$ & 11 & 11 & 12 \\
& 12.00 & & & \\
3 & $08.00-$ & 10 & 11 & 10 \\
& 12.00 & 10 & & \\
4 & $08.00-$ & 10 & 10 & 11 \\
\hline
\end{tabular}

Berdasarkan data mentah dari ketiga hasil pengukuran sebelum intervensi (A1), selama pemberian Intervensi (B), dan setelah pemberian intervensi (A2). Maka dapat dicari hasil rerata skor total dari keriga rater. Berikut ini analisis data yang dihasilkan dari hasil observasi yang ditampilkan dalam bentuk grafik. Setiap grafik mewakili rerata skor total dari ketiga rater berdasarkan tingkat perilaku menentang anak pada saat baseline awal (A1) selama 4 hari, pemberian intervensi (B) selama 2 hari, dan Baseline akhir (A2) selama 4 hari.

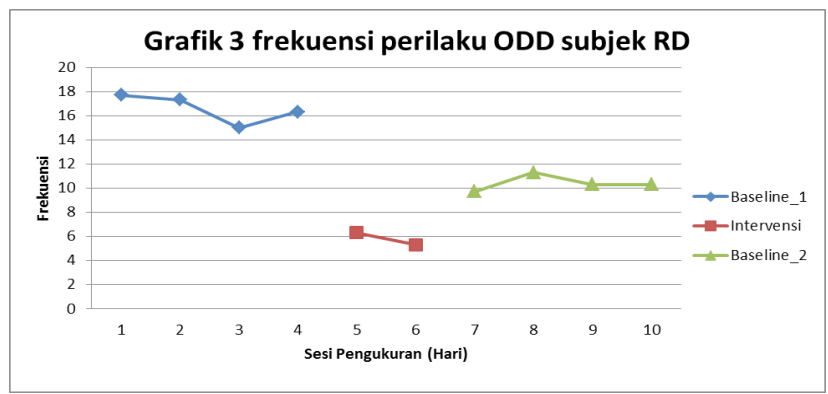

Berdasarkan data mentah dari ketiga hasil pengukuran sebelum intervensi (A1), selama pemberian Intervensi (B), dan setelah pemberian intervensi (A2). Maka dapat disimpulkan bahwa terdapat perubahan skor angka dari ketiga pengukuran di atas. Berdasarkan grafik pada gambar di atas tampak bahwa skor minimal frekuensi perilaku menentang pada pengukuran pada tahap awal (A1) ialah sebesar 15. Pada fase interven- 
si (B1) terlihat adanya perubahan grafik jika dibandingkan dengan sebelumnya ialah sebesar 5.3 sedangkan pada fase pengukuran akhir nilai terendah ialah 9.7 Sehingga dapat disimpulkan bahwa terdapat penurunan perilaku pada subjek RD baik sebelum dan sesudah diberikan intervensi.

\section{d. Subjek TGR}

Pengukuran dilakukan kepada subjek TGR melalui tiga rater, yang dilakukan melalui tiga tahapan pengkuran antara lain ialah pengukuran awal, pemberian intervensi dan pengukuran akhir. Adapun hasil pengukuran tersebut dijelaskan pada Tabel di bawah ini:

Tabel 10 Data mentah skor pengukuran awal (Fase A1)

\section{Subjek TGR}

\begin{tabular}{|c|c|c|c|c|}
\hline \multirow{2}{*}{ Hari } & \multirow{2}{*}{ Waktu } & \multicolumn{3}{|c|}{$\begin{array}{l}\text { Skor total pengukuran awal } \\
\text { (A1) }\end{array}$} \\
\hline & & Rater 1 & Rater 2 & Rater 3 \\
\hline 1 & $\begin{array}{c}08.00- \\
12.00\end{array}$ & 19 & 19 & 20 \\
\hline 2 & $\begin{array}{c}08.00- \\
12.00\end{array}$ & 21 & 21 & 21 \\
\hline 3 & $\begin{array}{l}08.00- \\
12.00\end{array}$ & 20 & 20 & 20 \\
\hline 4 & $\begin{array}{c}08.00- \\
12.00\end{array}$ & 17 & 17 & 17 \\
\hline
\end{tabular}

Pada sesi terapi data mentah yang peneliti temukan dijelaskan pada Tabel di bawah ini:

Tabel 11 Data mentah skor pengukuran pada saat terapi (Fase B)

\begin{tabular}{ccccc}
\hline & & \multicolumn{3}{c}{$\begin{array}{c}\text { Skor total pengukuran } \\
\text { tengah (B) }\end{array}$} \\
\cline { 3 - 5 } Hari & Waktu & Rater 1 & Rater 2 & Rater \\
& & & & 3 \\
1 & $\begin{array}{c}08.00- \\
12.00\end{array}$ & 8 & 8 & 8 \\
& $\begin{array}{c}12.08 .00- \\
2\end{array}$ & & & \\
& 12.00 & 6 & 6 & 6
\end{tabular}

Berdasarkan keterangan di atas, maka terlihat bahwa terdapat penurunan frekuensi gangguan perilaku menentang yang dialami oleh subjek. Sedangkan fase berikutnya ialah fase setelah intervensi yang diberikan kepada subjek. Adapun penjelasan data, dapat dilihat pada data di bawah ini:

Tabel 12 data mentah skor pengukuran pada saat terapi (Fase A2)

\begin{tabular}{ccccc}
\hline & & \multicolumn{3}{c}{ Skor total pengukuran } \\
Hari & Waktu & \multicolumn{3}{c}{ akhir (A2) } \\
\cline { 3 - 5 } 1 & & Rater 1 & Rater 2 & Rater 3 \\
& $08.00-$ & 10 & 10 & 9 \\
& 12.00 & 10 & & \\
2 & $08.00-$ & 13 & 13 & 14 \\
& 12.00 & 13 & & \\
3 & $08.00-$ & & 8 & 8 \\
& 12.00 & 8 & & 12 \\
4 & $08.00-$ & 12 & 12 & 12 \\
\hline
\end{tabular}

Berdasarkan data mentah dari ketiga hasil pengukuran sebelum intervensi (A1), selama pemberian Intervensi (B), dan setelah pemberian intervensi (A2). Maka dapat dicari hasil rerata skor total dari ketiga rater. Berikut ini analisis data yang dihasilkan dari hasil observasi yang ditampilkan dalam bentuk grafik. Setiap grafik mewakili rerata skor total dari ketiga rater berdasarkan tingkat perilaku menentang anak pada saat baseline awal (A1) selama 4 hari, pemberian intervensi (B) selama 2 hari, dan Baseline akhir (A2) selama 4 hari.

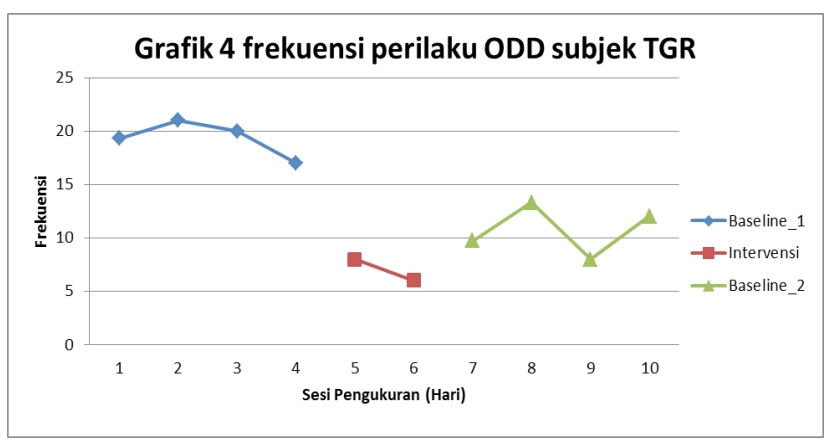


Berdasarkan data mentah dari ketiga hasil pengukuran sebelum intervensi (A1), selama pemberian intervensi (B), dan setelah pemberian intervensi (A2). Maka dapat disimpulkan bahwa terdapat perubahan skor angka dari ketiga pengukuran di atas. Berdasarkan grafik pada gambar di atas tampak bahwa skor minimal frekuensi perilaku menentang pada pengukuran pada tahap awal (A1) ialah sebesar 17. Pada fase intervensi (B1) terlihat adanya perubahan grafik jika dibandingkan dengan sebelumnya ialah sebesar 6 , sedangkan pada fase pengukuran akhir nilai terendah ialah 8 . Sehingga dapat disimpulkan bahwa terdapat penurunan perilaku pada subjek TGR baik sebelum dan sesudah diberikan intervensi.

\section{Analisis Deskriptif}

Analisis statistik selanjutnya adalah dengan menggunakan teknik analisis Wilcoxon Test untuk menguji perbedaan perilaku menentang pada subjek sebelum diberikan terapi dan sesudah diberikan terapi. Adapun jumlah perolehan skor antara baseline awal dan akhir terlihat pada Tabel 13 di bawah ini:

Tabel 13 Data baseline awal dan baseline akhir

\begin{tabular}{|c|c|c|}
\multicolumn{3}{|c}{$(\mathrm{N}=4)$} \\
Subjek & $\begin{array}{c}\text { Baseline } \\
\text { awal (A1) }\end{array}$ & $\begin{array}{c}\text { Baseline akhir } \\
\text { (A2) }\end{array}$ \\
\hline ADT & 79 & 36 \\
\hline AD & 59 & 36 \\
\hline TG & 63 & 42 \\
\hline RD & 77 & 43 \\
\hline
\end{tabular}

Hasil pengumpulan data pada baseline awal sebelum diberikan perlakuan menunjukan frekuensi gangguan perilaku menentang terendah 59 dan tertinggi 79 dengan rerata 69.50 Sedangkan pengumpulan data pada baseline akhir setelah perlakuan menunjukan frekuensi ganggu- an perilaku menentang terendah 36 dan tertinggi 43 dengan nilai rerata 39.25. Dari hasil analisis data didapatkan besaran $\mathrm{Z}=-1,826$ dengan nilai $\mathrm{p}=0,034<0,050$ sehingga dapat disimpulkan ada perbedaan signifikan frekuensi gangguan perilaku menentang antara sebelum dan sesudah diberikan terapi kognitif perilakuan pada di MTS X Yogyakarta. Subjek yang diberikan terapi kognitif perilakuan mengalami penurunan gangguan perilaku menentang.

\section{Analisis Kualitatif}

Secara keseluruhan, seperti yang terlihat pada histogram terjadi penurunan sebelum diberikan terapi kognitif perilakuan, dan sesudah diberikan terapi kognitif perilakuan. Hal ini menunjukkan bahwa terapi kognitif perilakuan efektif menurunkan frekuensi perilaku menentang. Tujuan analisis kualitatif adalah untuk mengetahui pengalaman peserta dalam mengikuti masing-masing sesi terapi. Selanjutnya perkembangan kemajuan subjek dari awal sampai akhir penelitian diuraikan dibawah ini:

\section{a. ADT}

Berdasarkan hasil wawancara serta observasi yang dilakukan, maka dapat disimpulkan bahwa, subjek merupakan siswa yang diindikasikan mengalami perilaku menentang. ADT dinilai anak yang kerap melanggar peraturan yang diberikan oleh guru, ADT pula dilaporkan pernah tidak masuk ke sekolah selama 1 minggu, ADT pula dilaporkan merupakan anak yang kerap melanggar aturan yang ada di sekolah seperti pernah melawan serta berselisih paham dengan guru di kelas. Selain itu, ADT merupakan siswa yang kerap mengganggu temannya yang lain seperti mengambil buku serta peralatan temannya di kelas. ADT pula jarang mengerjakan pekerjaan seperti mengisi soal dan mengerjakan PR di se- 
kolah. Sesekali pula ADT terlihat mudah tersinggung bila diberikan teguran oleh guru di kelas. Tidak mengenakan pakaian rapi serta kerap keluar masuk kelas tanpa tujuan yang jelas. ADT pula dinilai siswa yang mudah terpancing emosi, dan sering membuat keributan serta membuat gaduh di kelas.

Setelah intervensi diberikan, berdasarkan hasil wawancara yang dilakukan kepada guru di kelas, maka guru menyatakan saat ini ADT mulai mampu mengendalikan emosi, mulai mampu bersabar dan menunggu giliran dalam pembicaraan dan perilaku mengganggu temannya yang lain sudah mulai dikurangi. ADT pula terlihat mulai mengerjakan tugas yang diberikan oleh guru, mulai mentaati peraturan dan mulai tidak lagi dengan mudah tersulut dengan emosi. ADT pula mulai mampu menyelesaikan tugas yang diberikan oleh guru, walaupun terkadang perlu dingatkan oleh gurunya di kelas.

\section{b. AD}

Berdasarkan hasil wawancara serta observasi yang dilakukan, maka dapat disimpulkan bahwa, subjek merupakan siswa yang diindikasikan mengalami perilaku menentang. AD dinilai anak yang kerap melanggar peraturan yang diberikan oleh guru, AD pula dilaporkan merupakan anak yang kerap melanggar aturan yang ada di sekolah seperti pernah melawan serta berselisih paham dengan guru di kelas. Selain itu, AD merupakan siswa yang kerap mengganggu temannya yang lain seperti mengambil buku serta peralatan temannya di kelas.

Berdasarkan hasil wawancara yang dilakukan kepada guru di kelas, maka guru menyatakan saat ini AD mulai mampu mengendalikan emosi, mulai mampu bersabar dan menunggu giliran dalam pembicaraan dan perilaku mengganggu temannya yang lain sudah mulai dikurangi. AD pula terli- hat mulai mengerjakan tugas yang diberikan oleh guru, mulai mentaati peraturan dan mulai tidak lagi dengan mudah tersulut dengan emosi. AD pula dilaporkan mulai mampu mengurangi untuk tidak keluar masuk kelas tanpa sebab yang jelas.

\section{c. RD}

Berdasarkan hasil wawancara serta observasi yang dilakukan, maka dapat disimpulkan bahwa, subjek merupakan siswa yang diindikasikan mengalami perilaku menentang. RD dinilai anak yang kerap melanggar peraturan yang diberikan oleh guru, RD pula dilaporkan merupakan anak yang kerap melanggar aturan yang ada di sekolah seperti pernah melawan serta berselisih paham dengan guru di kelas. Selain itu, RD jarang mengerjakan tugas yang diberikan oleh gurunya di kelas. RD pula menyatakan bahwa apa yang dijalani di sekolah adalah hanya untuk bertemu dengan teman dan bermain di sekolah. Di sisi yang lain RD pula merupakan siswa yang kerap mengganggu temannya yang lain seperti mengambil buku serta peralatan temannya di kelas. Sesekali pula RD terlihat mudah tersinggung bila diberikan teguran oleh guru di kelas. RD kerap pula tidak mengenakan pakaian rapi.

Berdasarkan hasil wawancara yang dilakukan kepada guru di kelas, maka guru menyatakan saat ini RD mulai mampu mengendalikan emosi, mulai mampu bersabar dan menunggu giliran dalam pembicaraan dan perilaku mengganggu temannya yang lain sudah mulai dikurangi. RD pula terlihat mulai mengerjakan tugas yang diberikan oleh guru, mulai mentaati peraturan dan mulai tidak lagi dengan mudah tersulut dengan emosi.

\section{d. TGR}

Berdasarkan hasil wawancara serta observasi yang dilakukan, maka dapat disimpulkan bah- 
wa, subjek merupakan siswa yang diindikasikan mengalami perilaku menentang. TGR dinilai anak yang kerap melanggar peraturan yang diberikan oleh guru. TGR pula dilaporkan merupakan anak yang kerap melanggar aturan yang ada di sekolah seperti pernah melawan serta berselisih paham dengan guru di kelas. TGR pula jarang mengerjakan tugas yang diberikan oleh guru di sekolah, sehingga tak jarang pula TGR mendapatkan sangsi oleh sekolah. Selain itu, TGR merupakan siswa yang kerap mengganggu temannya yang lain seperti mengambil buku serta peralatan temannya di kelas. Sesekali pula TGR terlihat mudah tersinggung bila diberikan teguran oleh guru di kelas, seperti ketika ditanyakan tugas. TGR terlihat melakukan perlawanan dan menolak untuk menjawab dan mengabaikan apa yang menjadi tanggung jawabnya sebagai siswa di kelas. TGR pula kerap tidak mengenakan pakaian rapi serta kerap keluar masuk kelas tanpa tujuan yang jelas.

Berdasarkan hasil wawancara yang dilakukan kepada guru di kelas, maka guru menyatakan saat ini TGR mulai mampu mengendalikan emosi, mulai mampu bersabar dan menunggu giliran dalam pembicaraan dan perilaku mengganggu temannya yang lain sudah mulai dikurangi. TGR pula terlihat mulai mengerjakan tugas yang diberikan oleh guru, mulai mentaati peraturan dan mulai tidak lagi dengan mudah tersulut dengan emosi.

\section{PEMBAHASAN}

Berdasarkan hasil penelitian yang dilakukan menunjukkan bahwa ada perbedaaan signifikan antara frekuensi gangguan perilaku menentang sebelum dan sesudah diberikan terapi kognitif perilakuan pada siswa siswa MTS X Yogyakarta hal ini dilihat pada nilai $Z=-1,826$ dengan nilai $\mathrm{p}=0,034<0,050$. Jika dilihat berdasarkan hasil data kualitatif menunjukkan bahwa secara umum, peserta yang diberikan terapi menunjukkan adanya perubahan yang lebih baik, diantaranya ialah siswa mulai memahami bahwa pemahaman mengenai perilaku menentang ialah sesuatu yang salah. Siswa pula memahami bahwa seluruh kegiatan yang bersifat menentang akan berdampak pada menurunnya prestasi serta menjadikan siswa di jauhi oleh temannya yang lain. Siswa pula menyatakan bahwa dengan bersikap asertif maka akan memberikan dampak positif kepada siswa di kelas dan di rumah. Dalam terapi ini pula seluruh siswa menyatakan dengan bersikap tenang akan memberikan kenyamanan dalam menanggapi masalah.

Keberhasilan dalam terapi ini mendukung beberapa pernyataan dan penelitian sebelumnya yaitu mengenai pengaruh terapi kognitif perilaku dapat menurunkan gangguan perilaku seperti perilaku agresif, Conduct serta perilaku menentang. Pernyataan tersebut sebagaimana pernyataan yang dikemukakan oleh Adelman \& Taylor (2008) yang menyatakan bahwa terapi kognitif perilakuan sangat dimungkinkan diberikan kepada anak hingga remaja dengan gangguan perilaku seperti perilaku menentang dan perilaku merusak.

Penelitian lain ialah penelitian yang dilakukan oleh Ariati (2012) dengan teknik terapi kognitif perilakuan upaya menurunkan perilaku agresif pada remaja yang mengalami perilaku merusak, penelitian tersebut terbukti mampu mengurangi perilaku agresif pada remaja yang diindikasikan mengalami perilaku merusak. Terapi kognitif perilakuan pula pernah diteliti oleh Nindita (2012) dalam pengupayaan pengelolaan marah pada anak yang dindikasikan mengalami kecenderungan perilaku gangguan perilaku menentang, penelitian tersebut terbukti menunjukan bahwa ada penurunan tingkat kemarahan pada anak-anak yang diindikasikan mengalami per- 
ilaku gangguan perilaku menentang.

Program yang diberikan pada terapi ini ialah mengacu pada teori yang dikemukakan oleh Griffin, Huges, Kaplan, Kazdin (Matthys \& Lochman, 2010) yaitu berupa, Behavioral management, modeling, Problem solving skill, Social problem solving, Cognitive restructuring, Relaxation and self instructional training, yang selanjutnya peneliti buat ke dalam modul terapi. Kemudian selanjutnya, modul tersebut dijabarkan dalam 12 sesi yang dilaksanakan selama 2 hari.

Pada pertemuan pertama, adapun sesi yang diberikan antara lain ialah mengenai pembukaan, perkenalan serta kontrak terapi. jalannya terapi, diawali dengan perkenalan dan games yang bertujuan mencairkan suasana peserta agar dapat all out mengikuti terapi sehingga tumbuh saling menghormati, menghargai satu sama lain (Harjana, 1995). Pada sesi ini, seluruh peserta terlihat sangat sulit untuk dikendalikan hal ini dikarenakan seluruh siswa disibukkan dengan berbicara antar siswa dan kurang memperdulikan kegiatan terapi. Pada proses ini, seorang terapis berusaha membuat kondisi nyaman melalui kegiatan permainan yang melibatkan semua siswa. Melalui permainan "Gajah dan semut". Pada permulaan sesi ini dilakukan simulasi terlebih dahulu hal ini diharapkan agar peserta memahami apa yang dimaksud dengan games tersebut, setelah dirasa cukup memahami, terapis memulai permainan. Setelah selesai dan dianggap nyaman dan dekat dengan peserta. Terapi secara perlahan memberikan maksud dan tujuan dari agenda yang akan dijalani oleh peserta. Setelah dianggap peserta memahami, agenda selanjutnya ialah dilanjutkan dengan pemberian pohon harapan. Pada proses pemberian pohon harapan, terdapat beberapa indikator yang didapatkan oleh peneliti mengenai permasalahan yang sulit untuk dirubah oleh peserta antara lain ialah untuk tidak ramai di kelas, mengganggu teman, tidak mendengarkan guru. Pada sesi ini, terapis pula mengalami kendala untuk memberikan penyampaian kepada peserta dikarenakan karakteristik siswa dengan gangguan perilaku menentang sulit untuk diberikan arahan terdapat beberapa siswa yang tidak memahami. Ketidakpahaman tersebut selanjutnya terapis jelaskan secara perlahan apa yang sebenarnya menjadi masalah. Setelah selesai, sesi selanjutnya ialah dilanjutkan denan sesi ABC.

Pada saat Sesi ABC seluruh siswa diajarkan untuk mengetahui respon Lingkungan sosial yang dapat diterima oleh lingkungannya, Melalui ABC remaja akan dibantu untuk mengubah respon yang selama ini dimunculkan dalam lingkungan sosialnya yaitu respon yang diterima oleh lingkungan sosial, siswa pula diajarkan untuk dapat mengarahkan setiap perubahan perilaku yang ingin di capai dengan mempertimbangkan konsekwensi disekitarnya. Hal ini diperkuat dengan pernyataan yang dikemukakan Cormier (Nursalim, 2013) dalam sesi ini peserta akan diajak untuk dapat mengarahkan setiap perubahan perilaku yang ingin dicapai, hal ini pula seirama dengan pendapat yang dikemukakan oleh Jones, Nelson dan Kazdin (1977).

Pada sesi ini, seluruh siswa terlihat sangat antusias untuk mengikuti kegiatan terapi. Hal ini dikarenakan terapis memberikan contoh yang langsung dari akibat dari perilaku yang sering dilakukan oleh beberapa siswa yang ikut dalam terapis, misalkan salah satunya ialah siswa dengan inisial ADT. ADT ialah salah satu siswa yang dikenal nakal, tidak mengikuti aturan, tidak mau menjalankan rutinitas sebagaimana semestinya kegiatan yang dilakukan, melawan guru, mudah tersulut emosi oleh siswa yang lain, ADT pula pernah tidak naik kelas. Hal lain pula terapis mencontohkan, dampak dari beberapa perilaku yang dilakukan oleh $\mathrm{RD}$. 
RD ialah dikenal anak yang tidak mau mengerjakan tugas, sering membolos, jarang mengenakan pakaian yang rapi, tidak mau mendengarkan aturan serta kerap melawan guru dan berkata cenderung kasar. Dari kedua contoh tersebut mengakibatkan beberapa akibat atas perilaku yang ditimbulkan antara lain ialah menjadikan ADT tidak naik kelas, cenderung tidak diperdulikan guru, dan cenderung di jauhi oleh teman-teman yang lain. Hal ini pula dialami oleh RD. pada sesi ini, terapis mengajak peserta untuk menganalisis apakah perilaku yang biasanya dilakukan tersebut bisa diterima oleh lingkungan sekitar ataukah tidak. Begitu pula saat peserta berada di lingkungan rumah, apa yang akan menjadi dampak dari perilaku menentang yang dilakukan. Setelah sesi ini selesai, seluruh siswa mulai memahami bahwa dengan perilaku tersebut akan menjadikan siswa tidak akan diterima dengan baik oleh lingkungan sekitar, cenderung dijauhi, tidak bisa menjalankan rutinitas pelajaran dengan baik, tidak dapat mengerjakan pekerjaan sekolah dengan baik, sehingga dapat mengakibatkan rendahnya perolehan prestasi di sekolah. Setelah dianggap selesai, agenda dilanjutkan dengan sesi modeling.

Modeling dilakukan menggunakan film silent of love. Cuplikan film ini berisikan tentang orangtua yang bisu, dan seorang anak yang tidak menerima keadaan orangtua dengan cara menentang, marah, emosi serta mengacuhkan orangtua. Melalui sesi ini siswa diajarkan untuk dapat belajar secara langsung. Pada sesi ini terkadang Individu tidak menyadari bahwa pengaruh yang lebih besar adalah apa yang individu lakukan bukan apa yang individu katakan. Pendekatan ini merupakan pendekatan yang efektif untuk mengajarkan perilaku prososial, respon dalam penyelesaian masalah, dan ketrampilan problem solving yang menggunakan seorang coping model (Grif- fin, Huges, Kaplan, Kazdin dalam, Matthys \& Lochman, 2010).

Proses dari metode ini siswa dimintakan untuk melakukan observasi pada model dan melakukan indentifikasi apa saja perilaku yang dilakukan oleh model. Kelebihan dari modelling adalah salah satu strategi yang dapat dilakukan saat ini dan lebih baik daripada mendiskusikan secara abstrak tentang bagaimana menyelesaikan sebuah masalah. Modelling membantu untuk menangkap perilaku yang bermasalah dan perilaku coping, hal ini akan lebih bermakna dan mudah untuk diingat sebagai suatu proses pembelajaran. Beberapa anak atau remaja dengan gangguan perilaku biasanya tidak memiliki kesempatan untuk mempelajari ketrampilan penyelesaian masalah yang adaptif. Remaja dapat mempelajarinya dari teman dan orang dewasa (Mursalim, 2013).

Pada saat sesi dimulai, sebelumnya terapis meminta kepada seluruh peserta untuk mengambil posisi duduk yang nyaman dan tidak menghambat proses observasi dari film. Setelah dianggap kondusif, terapis menjelaskan agenda yang dilakukan ialah menonton film, pada sesi ini siswa diminta untuk menyimak, mengenal judul film, apa yang dilakukan oleh pemeran dalam film. Pemberian fim diberikan sebanyak 2 kali. Hal ini dikarenakan siswa kurang memahami isi dari film tersebut. Setelah dilakukan pemutaran ulang, siswa diminta untuk menjelaskan apa dari judul film, apa yang dapat dipahami dari film tersebut, perilaku apa yang dilakukan oleh pemeran dalam film. Keseluruhan siswa menjawab dengan tepat pada sesi judul film. Namun pada saat menjelaskan mengenai apa pelajaran yang didapatkan, peserta dengan nama TGR secara spontan mengeluarkan air mata. Setelah digali lebih jauh, siswa TGR menjelaskan bahwa saat ini kedua orangtua TGR telah bercerai, TGR merasa tidak diperdulikan, tidak ada yang men- 
yayanginya. Sehingga TGR menjelaskan bahwa dengan berperilaku melawan/menentang TGR beranggapan bahwa akan ada yang memperdulikannya terlebih pamannya yang ada di Yogyakarta.

Sedangkan peserta yang lain menjelaskan dengan judul yang sama serta menjelaskan bahwa, film tersebut berisikan tentang orangtua yang bisu dan seorang anak yang berharap ayahnya ialah bukan seorang ayah yang bisu. Anak tersebut seolah tidak dapat menerima keadaan ayahnya, dikarenakan ayahnya bisu, anak tersebut pula kerap menjadi bahan ejekan atas keadaan ayahnya. Sehingga anak tersebut tidak menerima, memberontak, marah, membentak, jarang kesekolah, kerap pulang malam hari. Selain TGR, peserta yang lain menyampaikan bahwa yang didapatkan dari film tersebut ialah ternyata apa yang diperbuat di rumah maupun di sekolah ialah sesuatu yang tidak baik terlebih perilaku menentang, membentak, marah kepada orang yang lebih tua atau orangtua maupun guru, karena apa yang diinginkan oleh orangtua atau guru ialah sesuatu yang baik untuk dijalankan. Setelah selesai terapis memberikan kesimpulan mengenai pelajaran yang dapat diperoleh dari film tersebut. Sesi diakhiri pada pertemuan pertama dan terapis menyampaikan bahwa agenda besok hari ialah akan melanjutkan kegiatan terapi, sehingga peserta diminta untuk dapat dengan tepat waktu.

Pada pertemuan kedua, sesi pertama diawali dengan pembukaan oleh terapis dan games. Games yang diberikan ialah games "Water melon" sesi ini dimaksudkan untuk mencairkan suasana, yang dipandu oleh Fasilitator. Pada sesi ini, seluruh peserta terlihat antusias dalam mengikuti kegiatan dan terlihat bersemangat. Setelah selesai, sesi dilanjutkan dengan cognitive restructuring, relaksasi dan self instruction. Terapis menjelaskan apa yang dimaksud dengan Cogntive restructuring. Dalam penjelasan yang diberikan, terapis menyampaikan bahwa metode Cogntive restructuring ialah metode untuk membantu remaja untuk mempertimbangkan beberapa pola yang salah dari lingkaran pikiran-perasaan-perilaku. Tujuannya adalah agar remaja mampu berpikir ulang mengenai pola yang lebih baik untuk mereka. Langkah pertama adalah proses membantu remaja mengindentifikasikan pikiran-perasaanperilaku yang selama ini terjadi sehingga ada kesempatan untuk Rewind dan replay. Langkah kedua adalah membantu remaja untuk mengakui bahwa pikiran berhubungan dengan perasaan dan tingkah lakunya dan hal tersebut dapat diubah. Setelah itu membantu remaja untuk mengindentifikasi pikiran dan keyakinan yang baru. Dalam sesi ini peserta akan diajak untuk mengenal dan memperhatikan serta menghentikan pikiran-pikiran negatif yang membuat individu menentang sehingga dapat digantikan dengan pikiran-pikiran yang lebih positif (Nursalim, 2013). Pernyataan di atas pula diperkuat dengan pernyataan yang dikemukakan oleh Lehay \& Rego (Donohue \& Fisher, 2012) menjelaskan bahwa dalam sesi ini peserta akan diajak untuk mengetahui akibat dari pikiran dan emosi yang salam dalam menginterpretasikan setiap kejadian sehingga dapat lebih selektif dalam memberikan penilaian.

Pelaksanaan sesi ini, seluruh siswa mengikuti dengan baik. Pada sesi ini mulai diketahui mengenai pikiran-pikiran yang salah terhadap permasalahan siswa di sekolah dan di rumah. Pada saat terapis menanyakan apa yang peserta pikirkan ketika ingin melawan, apa yang terlintas dalam pikiran peserta mengenai alasan tentang perilaku yang dimunculkan. Seluruh peserta menganggap bahwa perilaku menentang, melawan di sekolah ialah sesuatu yang wajar dilakukan. peserta menyatakan bahwa tidak mampu membedakan mana yang baik dan buruk untuk dilakukan 
hal ini diperparah dengan adanya masalah yang ada dilingkungan rumah. Adapun masalah yang dialami oleh seluruh peserta didasari oleh adanya permasalahan keluarga. Seperti kasus TGR, ADT, ialah salah satu korban perceraian orangtua sehingga perilaku menentang tersebut dilakukan adalah salah satu alasan agar TGR dan ADT untuk dapat diperhatikan oleh orangtua dan guru. Sesi ini dilanjutkan dengan relaksasi dan self instruction untuk mengubah kondisi emosi dan pikiran peserta.

Pelaksanaan sesi ini peserta diharapkan mampu mengontrol dirinya dalam setiap situasi yang berbeda yang dapat memunculkan terjadinya perilaku menentang. Dalam sesi ini peserta dibantu untuk menghindari reaksi yang berlebihan terhadap permasalahan yang dialami. Dalam pelaksanaannya, sesi ini dipadukan dengan self instruction. Self instructional akan membantu untuk menurunkan emosi dan secara hati-hati menilai situasi dan bereaksi terhadap kondisi sekarang.

Pelaksanaan sesi ini, peserta diminta untuk mengambil posisi yang paling nyaman tidak mengganggu peserta serta tidak membuat peserta menjadi terganggu. Pada saat sesi ini, seluruh peserta terlihat antusias dan kooperatif untuk mengikuti. Adapun relaksasi yang digunakan ialah menggunakan pendekatan safe place. Sesi ini peserta untuk memejamkan mata, untuk menarik nafas, melepaskan permasalahan, serta untuk menurunkan tensi pikiran yang berlebihan. Sesi ini disertakan pula self instruction yaitu untuk memasukkan afirmasi positif untuk mengubah pikiran serta perilaku peserta. Adapun yang pilihan kata yang disampaikan oleh terapis ialah, santai, tenang, bisa, yakin, dan apa yang dipikirkan oleh peserta ialah bukanlah sesuatu yang salah melainkan perlu dirubah sehingga hal tersebut menjadikan peserta menjadi lebih baik. Setelah sesi ini selesai, peserta diminta untuk menjelaskan apa yang dirasakan dari sesi ini, peserta menjawab memberikan efek yang tenang, sejuk, serta sebetulnya apa yang dilakukan selama ini bisa diubah dengan cara yang lebih tenang. Sedangkan pada sesi ini, berdasarkan hasil wawancara TGR menyatakan seolah membayangkah kondisi ini TGR berada dalam kondisi keluarganya yang utuh.

Sesi selanjutnya ialah melalui sesi problem solving skill. Hal ini bertujuan untuk membantu menyelesaikan konflik interpersonal. Program ini difokuskan untuk mengajarkan agar dapat menghargai lingkungan serta dapat mengatasi masalah yang di hadapi secara sosial. Dalam berbagai penelitian yang dilakukan problem solving skill yang diberikan kepada anak yang memiliki masalah perilaku, memberikan dampak pada berkurangnya perilaku mengganggu dan meningkatkan perilaku yang diterima secara sosial, dibandingkan dengan anak-anak yang tidak diberikan problem solving skill. Problem solving skill sangat berkorelasi dengan gangguan perilaku. Problem solving skill dibutuhkan karena remaja yang mengalami gangguan perilaku menentang kurang keterampilan untuk memecahkan masalah (Griffin, Huges, Kaplan, Kazdin dalam Matthys \& Lochman, 2010).

Pada sesi ini, peserta lebih di ajarkan untuk mengatasi masalah dengan cara yang lebih tepat serta diajak untuk dapat lebih asertif. Sesi ini lebih difokuskan pada sesi asertif. Adapun dari tujuan diberikan latihan asertif ialah peserta diminta untuk mengkoreksi perilaku yang layak dengan mengubah respon-respon emosional yang salah dan mengeleminasikan pikiran-pikiran irasional (Lazaruz dalam Nursalim, 2013). Pada saat pelaksanaan sesi, peserta terlihat kurang dapat memahami mengenai apa alasan diberikan latihan asertif. Setelah di berikan penjelasan oleh terapis. Peserta mulai memahami dan ikut 
serta dalam melaksanakan sesi ini. Sesi diawali dengan penjelasan apa yang dimaksud dengan asertif, agresif dan fasif. Pada sesi ini, terapis mencontohkan secara langsung apa yang dimaksudkan dengan asertif, agresif, fasif dalam komunikasi sehari-hari. Setelah selesai, sesi ini dilanjutkan dengan pemutaran video "Perilaku asertif non-asertif", video tersebut diperankan oleh 2 orang siswa dalam situasi kelas. Adapun isi video tersebut ialah apa dan bagaimana bentuk perilaku asertif seperti contoh ketika seseorang ingin memberikan komentar atas pekerjaan temannya. Peserta diajarkan untuk tidak agresif namun diarahkan untuk mlakukan dengan cara yang lebih asertif. Setelah pemutaran video selesai, terapis menjelaskan kepada peserta perilaku mana yang dianggap asertif. Peserta memberikan anggapan dengan mencontohkan bahwa pada sesi meminjam pena, memberikan masukan kepada teman ialah salah satu contoh dari perilaku asertif. Setelah selesai peserta diminta untuk melakukan role play. Peserta dimintakan untuk membuat 2 kelompok. Dalam tiap kelompok terdapat 1 peserta diminta untuk memainkan peran pelaku 1 peserta dimintakan untuk menjadi korban.

Pelaksanaan sesi ini, terlihat jelas bahwa siswa selama ini tidak mampu asertif. Hal ini diketahui dengan beberapa pernyataan yang dilontarkan oleh peserta antara lain ialah membentak, memaki, mengkritik serta tidak memahami apa dampak dari perilaku tersebut. Seluruh peserta diajarkan untuk mencari alternative solusi dari kebiasaan perilaku agresif menjadi lebih asertif. Peserta diajak untuk melakukan hal tersebut dan memberikan komentar tentang perilaku asertif. Keluruhan peserta menganggap hal tersebut sulit untuk dijalankan. Namun hal tersebut memberikan dampak positif kepada peserta. Peserta menganggap bahwa dengan asertif peserta dapat dengan lebih mudah untuk diterima oleh teman, orangtua dan guru di sekolah. Sesi ini diakhiri dengan memberikan kesimpulan mengenai apa yang didapatkan oleh seluruh peserta mengenai kegiatan yang dilakukan. Terapis menyampaikan pesan bahwa, terapi ini ialah bagian kecil yang dapat dilakukan, hal ini ialah sesuatu yang tidak akan berarti bila peserta tidak menjalankan segala kegiatan tersebut dalam keadaan yang sebenarnya, sehingga terapis berharap seluruh peserta dapat menjalankan.

Pada pelaksanaan Terapi kognitif perilakuan ini dilakukan secara berkelompok. Hal ini dikarenakan dengan pendekatan kelompok memiliki banyak kelebihan yang disebut dengan faktor teraputik, antara lain ialah peserta akan mendapatkan dukungan serta pembelajaran secara bersama sama sebagai bentuk dukungan atas perubahan yang ingin dicapai. Dengan diberlakukan secara berkelompok pula peserta dapat mengembangkan ketrampilan baru dari orang lain dalam kelompok (Yalom dalam Vinny, 2014).

Berdasarkan hasil penelitian ini, maka dapat disimpulkan bahwa dengan Terapi Kognitif Perilakuan dapat menurunkan perilaku menentang pada siswa di MTS X Yogyakarta. Dalam pelaksanaan penelitian ini terdapat beberapa kekuarangan dan keterbatasan dalam terapi. Adapun kekurangannya ialah mengenai fasilitas dalam pelaksanaan terapis seperti tata ruang dan alat pelengkap pelatihan. Selanjutnya ialah, mengenai waktu yang cukup singkat dalam pelaksanaan, hal ini dikarenakan peserta dalam waktu dekat akan melaksanakan ujian sekolah sehingga materi terapi lebih dipadatkan dan terapi ini hanya difokuskan pada aspek kognitif yang ada pada peserta dan tidak melibatkan orangtua subjek. Hal ini dikarenakan pada saat proses terapi, peserta menyatakan permasalahan tersebut selain peserta tidak mampu membedakan mana yang baik dan buruk ialah dikarenakan permasalahan keluarga. 


\section{SIMPULAN DAN SARAN}

\section{Simpulan}

Berdasarkan hasil penelitian yang dilakukan dapat disimpulkan bahwa secara perhitungan kuantitatif bahwa ada perbedaaan signifikan antara frekuensi gangguan perilaku menentang sebelum dan sesudah diberikan terapi kognitif perilakuan pada siswa siswa MTS X Yogyakarta hal ini dilihat pada nilai $\mathrm{Z}=-1,826$ dengan nilai $\mathrm{p}=0,034<0,050$. Sedangkan berdasarkan hasil data kualitatif menunjukkan bahwa secara umum, peserta yang diberikan terapi menunjukkan adanya perubahan yang lebih baik, diantaranya ialah siswa mulai memahami bahwa pemahaman mengenai perilaku menentang ialah sesuatu yang salah. Siswa pula memahami bahwa seluruh kegiatan yang bersifat menentang akan berdampak pada menurunnya prestasi serta menjadikan siswa di jauhi oleh temannya yang lain. Siswa pula menyatakan bahwa dengan bersikap asertif maka akan memberikan dampak positif kepada siswa di kelas dan di rumah. Dalam terapi ini pula seluruh siswa menyatakan dengan bersikap tenang akan memberikan kenyamanan dalam menanggapi masalah.

\section{Saran}

Berdasarkan penelitian yang dilakukan, peneliti memberikan saran bagi beberapa pihak.

1. Bagi Subjek penelitian

Hasil penelitian ini membuktikan bahwa terapi kognitif perilakuan dapat menurunkan frekuensi perilaku menentang pada siswa di MTS X Yogyakarta. Disarankan kepada siswa agar menerapkan beberapa ketrampilan yang sudah diajarkan oleh terapis terhadap upaya menurunkan perilaku menentang.

2. Bagi peneliti selanjutnya

Diharapkan lebih menyempurnakan penelitian selanjutnya dengan memperhatikan hal-hal yang dapat mempengaruhi, peneliti hanya menggunakan 4 peserta, sehingga disarankan untuk menambah jumlah peserta. Dalam terapi ini digunakan waktu hanya dalam 2 hari sehingga keterbatasan waktu mempengaruhi efek terhadap subjek antara lain kurang dapat mencermati materi lebih dalam. Sebaiknya durasi waktu dalam terapi ditambah agar subjek dapat merasakan efeknya lebih mendalam. Diharapkan kepada peneliti selanjutnya untuk dapat memantau secara berkelanjutan segala perkembangan peserta sehingga dampak dari terapi ini dapat terinternalisasikan dengan baik oleh seluruh peserta. Hal lain pula, peneliti berikutnya harus memastikan faktor yang menjadi penyebab. Hal ini dikarenakan pada saat penelitian, selain dipengaruhi oleh adanya distorsi kognitif, yang menjadi faktor penyebab ialah mengenai adanya masalah keluarga peserta. Sehingga harus diperhatikan terlebih dahulu mengenai latar belaka peserta.

3. Bagi sekolah

Dari hasil penelitian yang peneliti lakukan, terbukti bahwa dengan diberikan terapi kognitif perilakuan dapat menurunkan frekuensi perilaku menentang. Sehingga diharapkan kepada pihak sekolah dapat menjalankan terapi tersebut dalam upaya menangani perilaku menentang pada siswa yang lain. 


\section{DAFTAR PUSTAKA}

APA.(2000). Diagnostic and statistical manual of mental disorder. Washington DC: Author.

Adelman.H\& Taylor.L.(2008). Conduct and behavior problems: Intervention and resources for school aged youth. Los Angles: UCLA.

Ammerman, R.T. (2006). Personality and psychopathology. Canada : John Wiley \& Sons, Inc.

Ayu, T.L. (2012). Program kereta anak tertib untuk menurunkan perilaku distruptif anak taman kanak-kanak. Tesis (Tidak diterbitkan). Yogyakarta: Universitas Gadjah Mada

Baker, LL \& Scarth, K. (2002).Cognitive behavioral approach to threating children \& adolescents with conduct disorder. Ontarion: Childrens Mental Health.

Barlow, D \& Hersen, M. (1984). Singel-case exsperimental desain: Strategies for studying behavior chage. United States of America.

Belinda, A. (2012). Penerapan theraplay pada anak dengan oppositional defiant disorder. Tesis (tidak diterbitkan). Jakarta. Universitas Indonesia.

Beck, A.T.(2011). Cognitive therapy: Basics and beyond. New York : Guilford

Boyum, L. \& Parke, R. (1995).The role of family emotional expressiveness in the development of children's social competence. Journal of Marriage and the Family,57 (1), 593-608.
Biederman \& Spencer. (1996). Efficacy of play therapy with children: A Meta-analytic review of treatment outcomes: Journal professional Psychology: APA, 46 (2), 669-682.

Carr, A. (2001). Handbook of child and adolescent clinical psychology. London: Routlede

Crain, W. (2007). Teori perkembangan, konsep dan aplikasi (Edisi ketiga). Yogyakarta: Pustaka Pelajar

Cooper, J.L, Heron, T.E, \& Heward, W.L. (1987). Applied behavioral analysys. Ohio: Merrill Publishing Company.

Conover, W.J. (1980). Practical nonparametric statistic $\left(2^{\text {th }}\right.$, ed $)$, New York: John Wiley \& Sons, Inc.

Conners.K.C. 1989.Conners rating scale revised, instruments for use with children and adolescents. Australia: MHS.

Dattilo, L., Murphy, K. G., Van Eck, K., \& Flory, K. (2013). Do ADHD symptoms moderate the relation between positive alcohol expectancies and alcohol-related outcomes? ADHD: Attention deficit and hyperactivity disorders, 5, 93-104.

Desmita. (2012). Psikologi perkembangan peserta didik panduan bagi orangtua dan guru dalam memahami psikologi anak usia SD, SMP dan SMA. Bandung: Rosda Karya.

Fraser, A. (2008). Autralian family physician vol. 37, No. 4 2008. (www.Search.Informit.com ) didownload tanggal 8 Maret 2014. 
Fisher, J. \& Donohue, W. (2012). Cognitive behavioral therapy core principles for practice. New Jersey: John wiley \& Son, Inc

Foulkroud, K \& Davenport, B. (2010). An examination of empirically informed practice within case report of play therapy with aggressive and oppsitional Children. International Journal of play therapy. (3), 144-158.

Graham, P.J. (2005). Cognitive Behavioral Therapy for Children and Families. UK: Cambridge University Press.

Hairini. Kumara \& Uly. (2010). Parent management training untuk meningkatkan ketrampilan sosial anak yang mengalami oppositional defiant disorder. Jurnal Intervensi Psikologi, 2 (2), 249-268.

Haeba, N. (2011). Pengaruh terapi kognitif perilaku untuk mengurangi depresi pada pecandu cybersek. Jurnal Intervensi Psikologi, 3 (2) 233-244.

Joughin, C. (2003). Cognitive behavioral therapy can be effective in managing behavioral problems and conduct disorder in Pre-adolescenes. Evidence Nugget: 1-12.

Kaplan \& Sadock. (1997). Sinopsis psikiatri, ilmu pengetahuan perilaku psikiater klinis. Jakarta: Binarupa Aksara.

Kazdin, A. E.,Sigel, T. \& Bass.(1992). Cognitive problem-solving skill training and parent management training in the treatment of antisocial behavioral in children. Journal of Consulting and Clinical Psychology, 57, 733-747
Kendall, P. C. (1993). Cognitive behavioral therapy with youth: Guiding theory, current status, and emerging development. Journal of Consulting and clinical psychology, 61, 235-247

Klykylo, M \& Kay j. (2005). Clinical child psychiatry. Oxford: Jhon Wiley \& Sons.

Komnas PA. 2009. Jangan penjarakan anak, Http://janganpenjarakananak.blogspot.com diunduh pada tanggal 8 April 2014.

Kurniawan. Wahyu. (2011). Efektivitas pelatihan dzikir upaya peningkatan kebermaknaan hidup pada remaja akhir di asrama X Yogyakarta. Skripsi ( tidak diterbitkan) Yogyakarta. Universitas Mercu Buana Yogyakarta

Mash, E.J \& Wolfe. (2005). Abnormal child psychology. USA.Wadsworth Publishing Company.

Maslim, R. (2003). PPGDJ-III. Jakarta: PT Nuh Jaya.

Mack, K. (2004). Explanation for conduct disorder. Child \& Youth care forum, 33 (2): 95113

Matthys, W \& Locman, J. E. (2010). Oppositional defiant disorder and conduct disorder in childhood. Oxford: Jhon Wiley \& Sons.

Monk. Knores \& Haditono.(2001). Psikologi perkembangan, pengantar dalam berbagai bagiannya.Yogyakarta : Gadjah Mada University Press

Molina, Y (2012). Penerapan prinsip-prinsip 
PCIT pada anak usia prasekolah. Tesis (tidak diterbitkan). Jakarta: Universitas Indonesia

Miller, R.F. (2005). Parent child relationship factors associated with the diagnosis of oppostitional defiant disorder. A dissertation presented in partial Fulfillment of the requirements for the degree doctor of philosophy. USA: Proquest LLC.

Myers, A. \& Hansen C,H. (2006). Experimental psychology $\left(5^{\text {th }} \mathrm{ed}\right)$. Wadsword: Thomson Learning

Nurita, S. (2012). Pendekatan PCIT pada anak usia sekolah dengan perilaku disruptive. $T e$ sis (tidak diterbitkan). Jakarta. Universitas Indonesia

Nevid, J.S. (2005). Psikologi abnormal (Edisi keempat, jilid 2). Jakarta. Penerbit Erlangga

Nursalim, Mochamad. (2013). Strategi \& intervensi konseling. Jakarta Barat: Indeks

Santrock.(2007). Psikologi pendidikan (Edisi 3 buku 1. Jakarta: Salemba Humanika.

Schoreder, C. S \& Gordon, B.N. (2002).Assesment and treatment of childhood problems. New York: The Gulilford Press

Stallard, P. (2002). Cognitive behavioral therapy with children and young people: Journal of Behavioral and Cognitive Psychotherapy: (30) 297-309

Semiun, Y. (2006). Kesehatan mental 3. Yogyakarta: Kanisius

Sunanto, J. Takeuchi, K., \& Nakata, H. (2005).
Pengantar penelitian dengan subjek tunggal. Jepang : CRICED University of Tsukuba

Silver \& Ellison.(1995). Identifying and assessing self images in drawing by delinquent adolescents. The Art in psychotherapy; Vol 22, 336-352

Smith, S. W., Lochman, J. E. \& Daunic, A. P. (2005). Managing aggression using cognitive behavioral intervention: State of the practice and future directions. Behavioral Disorder, 30, 227-240

Vinny. Patricia. E. (2014). Pelatihan Mindfullnes untuk meningkatkan koping adaptif pada perawat psikiatrik di RSJ Provinsi Kalimantan Barat. Tesis (tidak diterbitkan). Yogyakarta. Universitas Mercu Buana Yogyakarta

Webster, Stratton \& Reid. (2008). Addressing multiple risk factors to improve school readiness and prevent couduct problems in young children. (www.Washington.edu) di download tanggal 8 Maret 2014

Webster, Stratton \& Reid. (2004). Treating conduct problem and strengthening social emotional competence in young children (Age 4-8 years): The dina dinosaur tretment program. (www.Washington.edu) di download tanggal 8 Maret 2014

Webster-Stratton, C., \& Reid, M. J. (in press). The incredible years parents, teachers and children training series: A multifaceted treatment approach for young children with conduct problems. In J. Weisz \& A. Kazdin (Eds.), Evidence-based psychotherapies 
for children and adolescents, 2nd edition. . (www.Washington.edu). di download tanggal 8 Maret 2014

Wilding, C \& Milne, A. (2013). Cognitive behavioral therapy (Seri Belajar Mandiri). Jakarta: PT Indeks

Wenar, C. \& Kerig, P. (2005). Developmental psychopathology: From infancy through adolescence $\left(4^{\text {the }}\right.$ d). New York : McGraw-Hill

Yanti, D. 2005. Efektivitas Art Therapy untuk meningkatkan ketrampilan sosial anak yang mengalami gangguan perilaku. Tesis (Tidak diterbitkan). Yogyakarta. Universitas Gajah Mada 